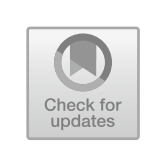

\title{
Governing a Quantum Society: Two Models
}

In a Quantum Society, the nation's top leadership circle, or government, should be a focus and source of inspiration, should reflect and reinforce the common vision and values that define that society, and direct a sense of national purpose. The very public figures who fill the posts of government should be men and women whose personal lives and personal behavioral and character examples reflect the fundamental values of the nation. They need to be exemplars and role models, "quantum leaders," as outlined in Chapter 11 .

The government of a Quantum Society must have in place a strong, central "operational system" that sets certain national values, standards and goals, legislates a basic legal framework that defines, and protects the rights and responsibilities of citizens and future generations, and has the centralizing capacity to organize and coordinate all more local elements of the system in times of national emergency or when urgent national priorities must be set. But in keeping with the principles of Quantum Management, all such standards and laws should reflect a commitment on the part of government to leave as much freedom as possible for citizens to live their personal lives as they want and to self-organize in specialinterest, community or local government groups as they wish. This is akin to the role the CEO plays in a quantum company. The head/heads of government, like the quantum CEO, guide, define, and set principles and standards by which national values are upheld and citizens protected, but 
they do not control the specific way that citizens or local groups live or self-govern within this shared framework.

Because China and America are now the two dominant superpowers, possessing the world's two largest economies, in our currently competitive global order, there is naturally fierce competition to decide which of their very different governing models should be the model of most popular choice. Each is bent on capturing the hearts and minds of developing countries, and even some of the more highly developed countries are taking a second look at their existing model. In asking whether the American democratic model or China's more centralized one-party model is the more "quantum," it is important to keep in mind that America is in many ways not typical of all liberal democracies, and China is far from typical of most authoritarian countries.

The individualism celebrated in America, and thus its social consequences, is far more radical than that cherished in many other democracies. The protection of individual rights like free speech and gun ownership, and unbridled freedom of the press, are also more extreme in America than in many other democracies. American mistrust of government, as well as the far less professional nature of its government and its dislike of elites and experts, are not shared by all other democracies, and the radically decentralized nature of American government is more extreme. And, of course, the world has always found American culture unique.

China's nature as a "civilizational state," over 3000 years old, and the many qualities and traditions developed during its long history that continue as advantages and characteristics of its modern governing style, make its, currently more authoritarian, rule radically atypical, and the consequences of it far more beneficial, than those shared by most other authoritarian states. A long tradition of great respect for learning and expertise that continues in modern China's placing high priority on quality education for all and expertise in government, and the resulting hugely professional nature and competence of its government, is of course atypical among far less developed, authoritarian states.

The massive anti-corruption campaign that President Xi Jinping launched in 2012 makes China's currently very low level of corruption in all public affairs atypical of most other authoritarian countries. Both a traditional Chinese respect for government, and the highly prized competent nature of its present government, make trust in, and voluntary cooperation with, government atypically high. Opinion surveys conducted in 
China by Western polling organizations (Pew Research Center) indicate that $87 \%$ of the Chinese population feels a high trust in the government. This trust also follows from a sense that China's current leaders are principled men and women of high integrity who genuinely do their best to serve the needs and aspirations of the Chinese people, which is not the case in most other authoritarian countries. The benefits to the general population of China's one-party rule are, therefore, atypically positive.

I suggested that the defining values of any Quantum Society include mutual respect, mutual responsibility, compassion, a celebration of diversity, social harmony, concern for the common good, and a conviction that government works to ensure these are practiced. Both China and America espouse such values, but judged in terms of actual practice, and the extent to which they are embedded in real social attitudes and behavior, and effective social outcomes, there is wide divergence between how their two differing models have performed.

Democracy itself as a political model was inspired by Newtonian atomism. Just as atoms were thought to be the building blocks of the universe, so individuals were thought to be the building blocks of society. Thus, individual freedom and the rights of the individual were the focus of all other governing principles. But starting with the Hippie social movement in the 1960s, and then augmented in the early 1980s by a neoliberal "Reganomics" that passed tax laws and regulations favoring newly strident and harsh capitalist business practices, these individualist principles have evolved into a radical individualism indistinguishable from selfishness and a selfish disregard for others and for the common good. "I have the right as an American to do what is best for me (or my company)," and "My only duty is to myself," became defining social mantras for many Americans. The possession of adequate wealth for self-sufficiency became a symbol of moral virtue, leading to a conviction that those who do not have it are "lazy" or morally flawed, and thus not deserving of compassion or help.

Other problems and shifts in social attitudes during the past fifty years have resulted in further strains on America's democratic model. Longstanding, systemic racism now combined with an exaggerated admiration for wealth and material success led to "this justice for some, and a different justice for others," undermining democracy's fundamental principle of equal justice under the law for all. Self-interest, and the corruption to which it often leads, have given over-weighted power to lobbyists 
and special interest groups and motivated politicians to influence election outcomes by manipulating (gerrymandering) the boundaries that define electoral districts. Both have greatly diminished an honest connection between the way citizens vote and the policies actually implemented by government.

Growing political polarization motivated by identity politics and party self-interest has crippled the consensus politics on which democratic government depends. And extreme interpretations of the democratic rights of free speech and freedom of the press, combined with the power of uncensored and divisive cable news channels like Fox and social media like Facebook and Twitter, have led to the spread of toxic misinformation, conspiracy theories, acts of domestic terrorism, and undermined and further fragmented the reasoned public discourse required for democracy to work. Free access to the internet has also enabled a proliferation of pornography and sexism that has undermined women's rights and undermined the moral tone of society.

Thus America today is a racially, socially, and politically fragmented nation with an effectively broken political system. Its once famous "melting pot" that celebrated the diversity characterizing "a nation built by immigrants" has morphed into fear and hatred of immigration. Its self-interested capitalism and business practices motivated by a selfish, mefirst mentality, and the political decisions bought to enable them, have sequestered $50 \%$ of the nation's wealth in the hands of $1 \%$ of its citizens. The low taxes paid by big corporations and the wealthy few have left a public budget inadequate to rebuild the nation's crumbling infrastructure or to maintain high standards and quality in its public educational system. Seventy million Americans live in conditions of poverty more commonly experienced in the Third World, its middle class is struggling on stagnated wages, and large numbers of Americans feel disenfranchised and betrayed by "the Establishment." The vast majority of Americans say they do not trust the government. All of this led to the populist uprising that resulted in Trumpism, and came to a head in America's inability to deal effectively with the Covid-19 pandemic. I fear it will take more than the election of Joe Biden to fix all this. A social revolution that resets American values and redefines the prevailing culture, embedded in new laws and political practices and a reform of political structures, would be required, and the distinctive political structures and culture of American democracy itself are weighed against this. 
Many other democratic nations are facing the same problems and challenges, though most to a still lesser extent, and anti-democratic populism is a growing threat in most of them. Throughout Europe, working-class voters feel their needs and concerns are neglected by an "elitist Establishment." Britain's self-destructive Brexit was a consequence of this. As in America, the consequences of the Covid pandemic, and their common failure to prevent them, have brought social strains, systemic incompetence, and lack of effective leadership to a head in much of Europe. In nearly all Western democracies, trust in government is low.

Some of democracy's growing problems arise from what gives legitimacy to power in all such systems. The democratic model requires frequent, regular elections, forcing its leaders to adopt short-term thinking and strategies, often addressing temporary and less vital "issues of the day," that will please the voters, inhibiting the more long-term, whole-system thinking needed to govern nations successfully as complex adaptive systems. And a democratic decision-making process that requires consensus among many disparate power groups is necessarily slow, making it impossible for these systems to respond quickly to rapid change or crises with effective, adaptive strategies. Throughout today's democratic world, many intellectuals, and even political leaders, are questioning the efficacy of democracy itself. In a late November 2019 leader essay, the Economist magazine spoke of a "global democratic recession." Both leaders and citizens are asking whether big reforms could make democracy work better or whether other governing options should be considered instead. Some are even wondering whether the Chinese model might be the preferred option.

The origins of China's more authoritarian political model, and of its collectivist culture that remains strong even today, lie in the traditional Confucian conviction that society at large is modelled on the family. Members of families feel they belong to each other, and that they have responsibility to each other and to the family as a whole. It is common that family members put each other and the best interests of family ahead of personal interest. Thoughtfulness and mutual support are necessary for family harmony and security, and kinship bonds are strong. Siblings may quarrel, they inevitably will develop in different ways, have different personalities and passions, and go their separate ways as adults, but they are always there for each other in times of need and never lose their sense of family duty and loyalty. Individual needs and preferences matter in 
modern China, but they always take second place to collective duty and loyalty.

This same sense of all being members of one big family, and an accompanying sense that the nation is a communal home, is strongly visible today in the way Chinese people feel and behave toward each other, in their sense of collective responsibility for maintaining cleanliness and order in shared public spaces, and their collective pride in and loyalty to their country. When I remarked to one of my students about the complete absence on city streets of any litter, even cigarette ends, and asked if this was because strict fines were imposed, he replied, "No. Some small fines exist, but this is not why the streets are so clean. It is our values. We Chinese feel the public space belongs to everyone, and therefore each of us has a personal responsibility to keep it clean. If I drop litter on the street, people passing by will tell me off!" This collective tidiness is facilitated by the presence every few meters on city streets of ubiquitous litter baskets.

According to Confucian traditions and values, respect for parents and elders extends to respect for rulers. Just as families should respect the authority of parents, societies should respect the rule of those who govern, but in turn, those who do so are expected to be "good parents." Rulers have a duty to protect all citizens from danger, meet their needs, and provide them with opportunities ensuring the best quality lives possible. When they do not do so, sometimes even Confucian citizens rebel. Throughout China's long history, the people never chose the Emperor, but the Emperor was expected to rule with the consent of the people. Tradition has it that there was a consistent pattern of six "good Emperors," followed by a seventh "bad Emperor." In response to the bad Emperor's poor leadership, the people rebelled, and then a new dynasty would come to power. From an historical perspective, today's ruling Chinese Communist Party is the current ruling dynasty, and though the people do not elect its "emperors," they know that they, too, rule with the consent of the people. This is the historical basis of what Western observers wrongly see as the Party's "cynical pact" with the Chinese people: leave the governing to us, and we will keep you safe and ensure you have a good standard of living.

The Communist Party's one-party rule, and its censorship policies that impose limits on the media, forbid large street protests and demonstrations, and limit free public (but not at all, private) speech, also stem from 
long tradition and ancient values, and from historical national catastrophes. Daoism, and its philosophical conviction that we live in a holistic and harmonious universe, emphasized that the harmony of Heaven must be mirrored by harmony here on Earth. Thus harmony was the primary social value, it remained so during Confucian times, and maintaining social harmony and national unity is still viewed as the primary political responsibility of today's ruling Communist Party. But assuring social harmony has never been easy at any time during Chinese history. Despite their strong collectivist culture, the Chinese people have always been an independent and strong-minded, fractious lot, frequently given to intrigues, plots, and occasional coups. They are also a very excitable people, easily riled up by emotion. Three times in China's history, their tendency to fragment into different ruling factions so weakened the nation's unity that foreign invaders were able to move in and seize power, each invasion resulting in the massacre of millions of Chinese people. Fear of such weakening disunity is never far from the mind of China's current government, and if at times they err, they tend to do so on the side of caution and control.

Nonetheless, the Chinese Communist Party is not the monolithic organization that foreign observers believe, nor does it govern the country without consulting the people. The Party itself has over 90 million members, over $8 \%$ of the total population, and these members are drawn from every sector of society, every age group, and every one of the country's fifty-six ethnic groups. Within the Party, five recognized factions openly debate their different approaches to Party policy, and the leader of one of these opposing factions is second in power only to President $\mathrm{Xi}$ Jinping. Other, smaller political parties also exist in China and are allowed to hold annual party conferences, though they have little voice and no power in how the country is run.

The vast and extensive Party structure extends into every university and company, and its descending levels of authority reach right down to neighborhood cells that deal with the most local issues. It is the duty of every Party member to attend regular meetings of their local cell, and each has the responsibility to report any problems or issues raised by citizens in their local region to these meetings. Such problems or issues that cannot be dealt with at local level must then be reported to whichever higher level of Party authority can address them. In addition, regular national opinion surveys are done in which citizens are asked if they are satisfied with their lives and living conditions. All this is meant to give 
credit to the Party's claim that the Chinese people do enjoy "democracywith-Chinese-characteristics." Of course, as was demonstrated in Wuhan during the very early stages of the Covid outbreak, local officials do not always have the competence to judge when a problem should be reported to higher authorities, or they may fear the disapproval of superiors if they do so. This is a problem of local government in all societies.

Such a vast Party machine responsible for organizing and responding to daily affairs at every level of society does require an equally vast bureaucracy, and this can make decisions and responsive actions painfully slow, often a source of frustration to individuals or groups waiting for them. And the various levels of authority empowered to make these decisions have a degree of self-organizing local autonomy, and some are not as efficient as others. But the almost miraculous speed and efficiency with which high-priority plans and decisions requiring concerted national effort can be achieved in China are due to central government's power to summon every level of the entire Party structure into coordinated action when required. It was America's lack of such centralizing power that partially accounted for its inability to cope with the Covid crisis more effectively. Few, if any, large democracies have this, and most would see it as a threat to the autonomy of local authority.

As I have said, Chinese culture has always highly valued learning and expertise. In Confucian times, all public officials, community leaders, and leading businessmen were expected to be "Confucian gentlemen," men distinguished by scholarship, expertise, and moral self-cultivation. Public officials who served the Emperor had to pass a very difficult exam proving a knowledge of the Classics. The modern Communist regime has only recently encouraged Chinese citizens to return to a knowledge of the Classics and traditional thought, but even Chairman Mao, who had simple rural origins, was a man of considerable learning. The moral selfcultivation of all citizens is encouraged by the ubiquitous public display of the country's twelve socialist values: four personal values of "patriotism," "dedication," "integrity," and "friendship"; four social values of "freedom," "equality," "justice," and "rule of law"; and four national values of "prosperity," "democracy," "civility," and "harmony." These are prominently posted in all public buildings, including public toilets, and in Shanghai I have seen them posted on every city lamppost in some neighborhoods.

Since Deng Xiaoping's chairmanship of the Party, all young people who hope to have a career in politics or public affairs must engage in a long 
leadership apprenticeship that combines learning and experience. After being invited to join the Party at age eighteen, a young person aspiring to high office must first become leader of their Party cell at their university or place of work. They then must progress to leadership of a neighborhood cell, followed by leadership of a city or rural district, mayor of a large city, governor of one of China's twenty-three provinces, membership of the Party Congress, and finally membership of the Party Central Committee. Only then can they aspire to membership of the powerful seven-member Politburo, and possibly the Presidency itself. Thus, every senior leader of the Chinese government has had experience, and gained a knowledge of the people, at every level of society. And even once in high office, every leader, even the President himself, must "go back to school" for a week or two each year to refresh their knowledge of current affairs, Party policy, and their own field of expertise. Several of China's recent presidents have been educated at Tsinghua University, and President Xi holds a Ph.D. from Tsinghua. This is how China assures great competency in high office.

Everyone in the world, including leaders of the world's democracies, has been impressed by China's miraculous and rapid development since Deng Xiaoping's "Great Opening Up" in 1979. In just forty-one years the country has progressed from being an extremely poor, rural nation to its present status as a great world power with the world's second, and soon to be, largest economy. By 2020, it had succeeded in its goal to raise one billion people out of poverty, and built a hyper-modern national infrastructure that would be the envy of any developed nation. Schools, universities, and hospitals were built, space science developed, and a tech industry that now leads in many sectors grew. China now leads the world in green energy development and artificial intelligence. In the short span of those forty-one years, China has progressed from the Age of Agriculture, through the Industrial Age, and now on to the Quantum Age.

The efficiency and speed with which this has been accomplished have of course been facilitated by one-party leadership that allows speedy implementation of huge, national planning with no need first to gain consensus between power blocks with differing views, and the ability to set ambitious long-term goals that do not require frequent voter consent. But in large part, all this progress has been due to wealth generated by China's new economic model, which in turn works so well because of Chinese values. Soon after assuming the presidency in 1989, Deng 
Xiaoping put in place a hybrid economic system combining the wealthgenerating advantages of capitalist free-market practices with socialist values that ensure this wealth benefits all of society. The Chinese call it "Socialism-with-Chinese-Characteristics."

China's economy comprises a combination of privately owned companies and state-owned ones. All profits from state-owned enterprises go directly back to the state budget to cover public costs and provide funds for social development. State ownership of a portion of shares in private enterprises provides further social funds. Both private and state-owned companies compete in the open, free market, though to date, due to their poor management and low employee motivation, state-owned companies have been far less profitable. Just recently, with this partly in mind, President Xi introduced a new "state capitalism" blending market mechanisms with government oversight. The goal of this is to better coordinate activities of the private and state sectors to achieve desired national targets, and the hope that state industries will learn better management practices from the private sector, while private industries will have their socialist values reinforced by practices in the state sector.

Owners of private companies do already contribute to social development through significant, voluntary charitable activities. A moderately wealthy friend of mine who owns a growing water treatment company is typical of his income bracket in paying for the establishment of a vocational high school in the rural village where he grew up. He also supported my research for two years. Leaders of larger private companies typically adopt a rural village, building a school, a health clinic, and upgrading its housing and infrastructure. Others fund cultural projects. Many of China's wealthy entrepreneurs spent their childhoods in poor rural villages and, having benefited from the country's public education opportunities to get where they are now, have a sense of wanting "to give back." One of the country's heroes is an early twentieth century, patriotic billionaire who owned a virtual empire of industries, and used many of his profits to build schools, orphanages, libraries, and hospitals, among other things.

Income from the state industries and shares in private companies, combined with this tradition of wealthy capitalists "giving back," has allowed the Chinese government to eradicate poverty, provide quality education and basic health care for all, and finance its ambitious infrastructure projects, while at the same time keeping taxes at a moderate level. Personal income tax is pegged at $19 \%$, and standard corporate tax $25 \%$, 
though this is reduced to $15 \%$ for industries like the tech sector that the government feels promote national development. Chinese entrepreneurs are allowed to get very rich-recently, five new billionaires have been created every week, and there is great income inequality in China, but instead of causing social resentment, this only seems to inspire ambition. People work very hard, but in turn everybody has the basic necessities of a decent life that can be lived with dignity, and everybody can aspire to realizing "the Chinese dream."

After forty-one years of massive growth and development, China today is a harmonious and well-ordered society at peace with itself and dazzling with palpable energy and innovation. People are friendly and polite to each other, even if total strangers, and especially so to foreign visitors like myself. There is no "otherness." Crime is low, the streets safe, and I feel very comfortable walking alone late at night in any big city neighborhood. High-rise life in crowded cities is compensated by easy access to green spaces and large, beautiful parks. As I observe people going about their business of daily life, I sense an air of general contentment, and small touches like special paths for the blind on all city pavements, featuring braille carvings to guide them around dangers, indicate government thoughtfulness about people's needs. As a frequent guest in China, weighed down by the constant bad news and reports of crises and disasters that feature in our Western media, I even derive a perverse relief from press censorship that mandates newspapers publish only happy, upbeat, and inspiring stories!

China is not, of course, a perfect country wholly without problems. All people, including university students and senior executives, work long hours, six days a week. Housing conditions and family rights for the millions of migrant workers who build China's expanding cities could be better, and working conditions in many factories could still improve. And, of course, there are the human rights issues relating to one of the country's ethnic minorities, that provide valuable anti-Chinese propaganda for Western interests, though these are less disturbing than civil rights deprivations suffered by African Americans due to centuries of systemic racism. Chinese intellectuals would like to see less censorship of the media and public debate. But no human society will ever be a perfect "quantum society." Throughout the whole of human history, all great powers have had their dark, or "shadow" side. As the Chinese would express this, "Where there is yang, there is also always yin." The measure of a society's strength, and the success of its political model, is whether the benefits 
to its citizens outweigh any problems they may suffer, and the extent of change necessary to address these problems.

I have suggested that for American democracy to repair its destructive divisions and to work for all its people, a social revolution and significant political restructuring would be required. And it remains an open question whether, in large and diverse, modern societies, any democratic system resting on frequent and universal, popular elections, and the need for multi-party consensus, can cope with the rapid change, uncertainty, complexity, large-scale challenges, and unlimited access to social media that typify life in the twenty-first century.

For China to address any current problems or discontent, no social revolution or major political restructuring would be required. Growing wealth will bring shorter working hours and better factory conditions where needed. Human rights issues would simply require the governing Communist Party to make better use of positive motivation when dealing with troublesome ethnic minorities and to loosen up a bit on censorship of the media and public speech. Its one-party, more authoritarian, political model is working very well for the vast majority of the Chinese people, and it has proven itself intelligent and efficient in coping with twenty-first-century challenges.

Whether the democratic model has failed America, or America has failed the democratic model, perhaps cannot be said. But judging by performance and delivery during these past forty years, the present state of American and Chinese societies, and likely ability to cope with future challenges and opportunities, my own experience and observations lead me to believe that the more professionally competent and efficient Chinese, one-party model, has produced something much closer to a quantum society than the American democratic model. But it remains an open question whether a model relying so greatly for its success on the distinctive character of Chinese culture and the Chinese people would work as well outside China itself. Quantum physics teaches us there is no "one best way," and perhaps any political model, if practiced in its ideal form, could deliver the benefits of a quantum society. 
Open Access This chapter is licensed under the terms of the Creative Commons Attribution-NonCommercial-NoDerivatives 4.0 International License (http:// creativecommons.org/licenses/by-nc-nd/4.0/), which permits any noncommercial use, sharing, distribution and reproduction in any medium or format, as long as you give appropriate credit to the original author(s) and the source, provide a link to the Creative Commons license and indicate if you modified the licensed material. You do not have permission under this license to share adapted material derived from this chapter or parts of it.

The images or other third party material in this chapter are included in the chapter's Creative Commons license, unless indicated otherwise in a credit line to the material. If material is not included in the chapter's Creative Commons license and your intended use is not permitted by statutory regulation or exceeds the permitted use, you will need to obtain permission directly from the copyright holder.

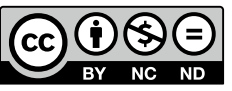

